(c) Колесник М. О., Дріянська В. Е., Драннік Г. М., Петрина О. П., Величко М. Б., Непомнящий В. М., 2017

УДК: 612.017.1:616.611-002-036.12+616.61-008.6

\author{
М. О. КОЛЕСНИК, В. Є. ДРІЯНСЬКА, Г. М. ДРАННІК, \\ О. П. ПЕТРИНА, М. Б. ВЕЛИЧКО, В. М. НЕПОМНЯЩИЙ
}

АСОЦІАТИВНІ ЗВ’ЯЗКИ НЦА 3 ВИСОКИМ РІВНЕМ ЦИТОКІНІВ КРОВІ, ЩО МАЮТЬ
ПРОТИЗАПАЛЬНІ ВЛАСТИВОСТІ, У ХВОРИХ НА ХРОНІЧНИЙ ГЛОМЕРУЛОНЕФРИТ

M. KOLESNYK, V. DRIYANSKA, G. DRANNIK, O. PETRINA, M. VELYCHKO, V. NEPOMNYASCHIY

\title{
ASSOCIATION OF HLA AND CYTOKINES OF BLOOD WITH ANTIINFLAMMATORY EFFECTS IN PATIENTS WITH CHRONIC GLOMERULONEPHRITIS
}

ДУ «Інститут нефрології Національної академії медичних наук України»

SI «Institute of Nephrology Academy of Medical Sciense of Ukraine»

Ключевые слова: антигены гистосовместимости, про- и противовоспалительные цитокины, хронический гломерулонефрит, нефротический синдром.

Key words: HLA, pro- and anti-inflammatory cytokines, chronic glomerulonephritis, nephrotic syndrome.

Резюме. Цитокины и НLA играют важную роль в иммуногенезе многих заболеваний, поэтому анализ этих показателей и их ассоциативных связей у больных гломерулонефритом (ГН) может определить их значение как дополнительных прогностических маркеров.

Цель работы: выявить ассоциации высокого уровня сывороточных цитокинов (IL-4, IL-17) и особенностей HLA для дальнейшего обоснования иммуногенеза хронического гломерулонефрита с нефротическим синдромом (ХГН, НС) и установления дополнительных маркеров прогнозирования его течения.

Материалы и методы. Изучали распределение НLА у 264 больных ХГН, НС (диагноз подтвержден методом нефробиопсии) и 350 здоровых доноров. Проводили типирование лимфоцитов стандартным микролимфоцитотоксическим тестом (Терасаки) с использованием панели анти-НLA сывороток (20 антигенов локуса А, 31антиген - локуса В и 9 антигенов-локуса DR). Этиологическую фракцию (атрибутивный риск) определяли по формуле : $\sigma=x-y / I-y$, где $x$ - частота антигена у больных, а y - у здоровых. Достоверным считали показатель б более 0,1 .

Методом ИФА исследовали в сыворотке крови уровень IL-14 у 76 и IL-17 у 79 больных («Вектор Бест», PФ), анализировали ассоциативные связи с особенностями HLA-фенотипов .

Результаты. У больных ХГН, НС показана ассоциация со следующими антигенами гистосовместимости - HLA-A23, -A24, -A28; -B8, -B38, -B41, -B44; -DR1, -DR4, -DRw52 (RR 2); из них причинная роль с абсолютным риском ( $(\geq 0,1)$ установлена для HLA-A24, -A28, -B8, -DR1, - DR4, - DRw52.

У пациентов с ХГН, НС достоверно повышены уровни сывороточных IL-4 и IL-17, наиболее высокие показатели обеих цитокинов - при наличии в фенотипе антигенов абсолютного риска ХГН, HC - HLA-A24, -A28, а сывороточный уровень IL-17 повышен также у носителей B14 и B38, ассоциирующих с гормончувствительностью. Убольных ХГН, НС антиген В8, ассоциирующий с гормонрезистентностью, чаще выявляется при более низком (хотя и выше нормы) уровне в крови больных противовоспалительного IL-4.

Заключение. Установлены ассоциации между НLА и сывороточными уровнями противовоспалительного $I L-4$ и IL-17, имеющего про- и противовоспалительные свойства, у больных ХГН, НС, что можно учитывать в качестве дополнительных прогностических предикторов.

Summary. Cytokines and HLA take important part in immunogenesis of many diseases, therefore the analysis of these indices and this associations in dependence of glomerulonephritis $(G N)$ can define their value as the additional prognostic markers.

Aim of the work is to determine the of associations the high serum levels of cytokines $(I L-4, I L-17)$ and peculiarities of some HLA in phenotype to substantiate of chronic glomerulonephritis with nephrotic syndrome (CGN, NS) immunogenesis and to ascertain the additional prognostic markers.

Materials and methods. There was studied the HLA-antigens distribution in the 264 adult patients CGN, NS (the diagnosis was confirmed morphologically using the thin needle nephrobiopsy) and 350 healthy donors by typing the lymphocytes with the aid of standard microlymphocytotoxic test

Дріянська Вікторія Свгенівна victoriadriyanskaya@gmail.com
(Terasaki's test). HLA antigens were defined using a standard microlymphocytotoxic test on the Terasaki's planchette with special panels of anti-HLA serums (20 antigens of locus $A, 31$ - B and 9 - DR). The etiologic fraction (attributive risk 
$s)$ was counted using the formula: $\sigma=x-y / I-y$, where $x$ - frequency of antigen in patients and $y$ - frequency in healthy.

The $\sigma$ reading was considered significant when it exceeded 0,1 .

Using ELISA, the level of the cytokines was studied in the blood serum - IL-4 in 76 and IL-17 - 79 patients.

Results. HLA-A23, -24, -28, - B8, -38, -41, -44, DR1, -4, -w52 in adults patients have associations (RR $\geq 2) C G N$, $N S$; the attributive risk $(A R)(\sigma \geq 0,1)$ to develop $G N$ detected in patients have A24, A28, B8, DR 1, 4, w52.

The CGN, NS patients has statistically higher serum level of the IL-4 and IL-17, with more high indices of this cytokines in patients with attributive risk antigens HLA-A24 and A-28. The highest levels of IL-17 detected also in adults case have B14 and B38, which associated with steroid sensitive NS. HLA-B8, which associated with steroid resistant NS, have more patients with CGN, NS with lower serum level of antiinflammatory IL-4.

Conclusion. The patients with CGN, NS have associations of HLA and serum levels of pro- and antiinflammatory cytokines IL-4 and IL-17, which play role of additional prognostic predictors.

ВСТУП. Генетична детермінованість багатьох патологій з визначенням механізмів їх реалізації є дуже важливим напрямком досліджень і серед таких захворювань важливе місце займає гломерулонефрит (ГН).

Аналіз даних щодо розподілу HLA у хворих залежно від особливостей показників прозапальних цитокінів, наведений в попередній публікації [6], показав важливу роль антигенів А10, А23, А24, А28, B8, В41, В44 та) та їх взаємозв'язок з підвищенням сироваткових рівнів TNF- $\alpha$, IL-18, MCP-1 в розвитку та прогресуванні хронічної хвороби нирок (XXН) у хворих на ГН, НС.

Не менш важливим є стан протизапальних реакцій імунної системи, про який можна судити за даними функціональної активності клітин по продукції відповідних медіаторів. Найбільш відомим 3 протизапальних цитокінів є IL-4, який стимулює гуморальну ланку імунітету. Це сильний ростовий фактор для В лімфоцитів, що сприяє активації клітин у стані спокою, підсилює продукцію $\mathrm{Ig}$ Е и Ig G1. Він $€$ антагоністом для деяких цитокінів, пригнічуючи секрецію макрофагами IL-1, IL-6 та TNF- $\alpha$, підвищуючи експресію антигенів HLA I і II класів, підсилюючи проліферацію Т лімфоцитів і зрілих активованих T-клітин. IL-4 сприяє дозріванню дендритних клітин, разом 3 іншими цитокінами призводить до підвищення їх антигенпрезентуючої здатності [9, 12]. IL-4 може бути задіяним у патогенезі гломерулонефриту [14]. Дефіцит цього лімфокіну в дебюті захворювання, на думку деяких авторів, не може зупинити розвиток запального процесу, чим сприяє його генералізації та більш тяжкому перебігу [7, 8].

В 1995 році з'явились перші роботи, в яких було показано існування окремої, відмінної від T хелперів 1 і 2 типів, субпопуляції CD4+ клітин, які продукували переважно IL-17 і були названі Т-хелпери 17 (Т-х 17). Диференціювання Т-х 17 із наївних CD4+-T-лімфоцитів відбувається поетапно: під впливом TGF- $\beta$, IL-6 i IL-1 наївні СД+4 Т-лімфоцити починають перетворюватись в клітини попередники Т-хелперів 17, в подальшому під впливом IL-23 вони дозрівають в Т-х 17, котрі продукують, крім IL-17, прозапальні цитокіни (TNF- $\alpha$, IL-6, -8, -23, MCP-1 [1, 13].

Головна функція цитокінів із сімейства IL-17 (A, F i E) прозапальна. Вони залучають в запальну реакцію велику кількість різних клітин, за рахунок індукції експресії таких цитокінів як IL-6, -8, ГМКСФ, Г-КСФ, а також хемокінів і металопротеїназ. Важливу роль цитокіни сімейства IL-17 відіграють в рекрутуванні, активації і міграції нейтрофілів; вони здатні викликати розвиток аутоімунного захворювання [13].

Протягом останніх років з'явилися дані шодо протизапальних ефектів IL-17 [11, 15, 17, 18], що дозволяє характеризувати цей лімфокін в даній публікаціï, не заперечуючи і його прозапальних властивостей.

МАТЕРІАЛИ І МЕТОДИ. Вивчали розподіл HLA-антигенів у 264 хворих на хронічну хворобу нирок I-II стадії, гломерулонефрит з нефротичним синдромом (XXH I-II, ГН, НС) з підтвердженим методом нефробіопсії діагнозом та у 350 здорових донорів. Досліджували показники сироваткових рівнів IL-4 у 76 пацієнтів та IL-17 у 79 хворих цієї категорії та у групі контролю.

HLA визначали за допомогою стандартного мікролімфоцитотоксичного тесту на планшетах Терасакі з застосуванням спеціальної панелі анти-HLA сироваток (20 антигенів локусу А, 31 - В і 9 - DR). Лімфоцити, що підлягали типуванню, виділяли з гепаринізованої периферичної крові шляхом центрифугування у градієнті щільності фікол-верографіна.

Групу контролю склали 350 здорових донорів 3 м. Києва.

Достовірність різниці у частоті визначення HLA-антигенів, що порівнювалися, оцінювали за допомогою критерію хі-квадрат для таблиць $2 \times 2$. У випадках, коли один з показників був менше 10, для оцінки достовірності різниці використовували точний метод Фішера. Величину відносного ризику захворювання (RR) визначали за коефіцієнтом:

$\mathrm{RR}=$ аб/вг, де a - кількість хворих, позитивних за даним антигеном, б - кількість осіб у контролі, негативних за даним антигеном, в - кількість хворих, негативних за даним антигеном, г - кількість осіб у контролі, позитивних за даним антигеном. При цьому значимими вважали показники RR>2,0 [3].

Етіологічну фракцію (абсолютний або атрибутивний ризик, $\sigma$ ) підраховували за формулою: $\sigma$ $=\mathrm{x}-\mathrm{y} / 1-\mathrm{y}$, де $\mathrm{x}-$ частота антигену у хворих, а y - частота у здорових. Даний показник дає змогу об'єктивно оцінити причинну роль у етіопатогенезі захворювання одного з декількох антигенів-провокаторів, для яких RR складав $>2,0$. Достовірним вважали показник $\sigma$ більший 0,1 [3]. 
Рівень IL-4, IL-17 в сироватці крові визначали за допомогою IФА на аналізаторі «SunRise TouchScreen», використовували тест-системи „Вектор Бест” (РФ). Для аналізу особливостей їх продукції залежно від HLA-фенотипу для кожного з вивчених медіаторів групи хворих ділили на групи з високими показниками (1 гр - втричі вище за норму) та помірно збільшеними (2 гр). Показали розподіл антигенів в цих групах та достовірність різниці їх зустрічаємості (p) за допомогою пакета програм "SPSS for Windows. Версія 11" та "MedStat". Для статистичної обробки використовувались параметричні критерії статистики (тест Ст'юдента) та непараметричні (критерій Уілкоксона). Достовірною вважали різницю при $\mathrm{p}<0,05$.

РЕЗУЛЬТАТИ І ОБГОВОРЕННЯ. Наші дослідження останніх років показали, що предикторами розвитку ХГН, НС у дорослих $є$ наявність в фенотипі A23, A24, A28; B8, B38, B41, B44; DR1, DR4, DRw52, з яких етіологічну фракцію обумовлюють A24, A28, B8, DR1, DR4, DRw52 (таблиці 1-5).

Вивчення функціональної активності клітин за даними рівнів відповідних цитокінів в крові хворих на ХГН, НС показало, що середній сироватковий рівень IL-4 був достовірно вище норми, визначеної у умовно здорових - відповідно, $57,8 \pm 4,5$ в порівнянні з 16,1 $\pm 0,7$ пкг/мл ( $<0,001)$.

В 1 гр. хворих увійшли пацієнти з рівнем IL4, що втричі перевищував норму (вище 45 пкг/мл), інші складали 2 гр. Порівняння груп показало достовірну різницю середніх рівнів цих груп - відповідно, $65,2 \pm 2,2$ та $30,5 \pm 1,8$ пкг/мл $(\mathrm{p}<0,001)$.

У хворих з найбільш високими рівнями IL-4 (1 гр) достовірно частіше, ніж взагалі у хворих на ХГН, НС, виявляються НLA-A28 $(\mathrm{p}=0,031)$ і A24 $(\mathrm{p}=0,030)$, частота якого достовірно перевищувала показник 2 гр. $(\mathrm{p}=0,020)$. Ці обидва антигени обумовлюють абсолютний ризик ХГН, НС (табл. 1). Частота HLA-A28 і A24 у разі найвищої продукції IL-4 (1 гр пацієнтів) також достовірно перевищувала зустрічаємість цього антигену серед здорових донорів $(\mathrm{p}<0,001)$. При дослідженні частоти антигену A24 у хворих 2 гр. і контрольної групи різниці не виявлено $(\mathrm{p}=0,719)$.

Звертає увагу, що частота А10 в групах не відрізнялась, але в 2 гр. мала тенденцію до більш високої $(p=0,098)$ (див. табл. 1). Хворих розділили на групи за наявністю цього антигену (І група - 17 хв.) та без нього (II група - 55 хв) і відмітили, що сиро-

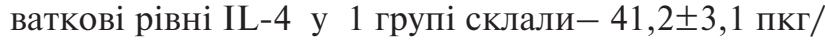
мл та у II групі-52,3 $\pm 2,9$ пкг/мл $(\mathrm{p}=0,067)$. За нашими попередніми даними [5], цей антиген відноситься до найбільш прогнозонегативних, асоціюючих з погіршенням функції нирок і розвитком ХXН $\mathrm{V}$ ст., тому можна вважати його асоціацію з більш низькою продукцією IL-4 як протизапального медіатора підставою для подальшого аналізу. Антиген А2 зустрічався в 1 гр. достовірно рідше, ніж в цілому у хворих $(\mathrm{p}=0,018)$ (див. табл. 1$)$.
Аналіз локусу В виявив більш виражене підвищення частоти антигенів В8 і В44 в 2 гр в порівнянні як з хворими на ХГН в цілому- відповідно, $p=0,010$ i p=0,002, так i 3 групою контролю $(\mathrm{p}<0,001)$; при порівнянні груп між собою різниця достовірна для HLA-B8 (p=0,026) (див. табл. 2).

Ці антигени також несуть відносний ризик захворювання на ХГН, НС, а В8 - асоціює зі стероїдорезистентністю [4]. Розподіл хворих на групи з наявністю HLA-B8 (I - 26 хв.) та без нього (II - 46 хв) підтверджує цю різницю - 42,9 44,2 та $54,2 \pm 2,9$ пкг/ мл $(\mathrm{p}=0,028)$, тобто наявність В8 асоціюе $з$ більш низьким рівнем IL-4 (хоча його значення вищі порівняно з нормальними в обох групах).

Більш високою була і частота антигену В14 в 2 гр. $(p=0,013)$ в порівнянні з усіма хворими, але різниця між групами 1 і 2 недостовірна $(\mathrm{p}=0,571)$, так само як і в групах з його наявністю (I) та його відсутністю (II) - $\mathrm{p}=0,584$ (табл. 2).

Не виявлено достовірної різниці частоти зустрічаємості антигенів локусу HLA-DR залежно від рівня IL-4 в сироватках крові пацієнтів хворих на ХГН, НС (табл. 3).

Таким чином, аналіз розподілу HLA-антигенів в групах показав достовірні відмінності частоти зустрічаємості антигенів А24 і В8, що обумовлюють атрибутивний ризик ХГН, HC: високі рівні IL-4 за наявності HLA-A24 i, навпаки більш низькі за наявності антигену В8.

Це підкреслює значущість його рівнів для розвитку та перебігу ХГН. Можливо, це пояснюється неоднозначним впливом IL-4 як протизапального, але стимулюючого продукцію імуноглобулінів, оскільки відомо, що IL-4 пригнічує продукцію прозапальних цитокінів IL-1, -6, TNF- $\alpha$, в той же час він проявляє прозапальну дію - посилює цитотоксичну активність макрофагів, сприяє міграції в осередок запалення нейтрофілів, посилює продукцію колонієстимулюючих факторів [10].

Одночасно IL-4 пригнічує продукцію макрофагами супероксидних і нітроксидних радикалів і порушує відповідь макрофагів на дію окремих субкласів імуноглобулінів, змінюючи експресію відповідних FcR. IL-4 посилює експресію продуктів MHC 2 класу та антигенпрезентуючу активність допоміжних клітин. В цьому відношенні IL-4 $є$ функціональним аналогом IFN- $\gamma$, хоча в багатьох інших ситуаціях він виступає як його антагоніст [2].

Не можна виключати, що виявлені асоціації рівнів IL-4 з наявністю антигенів-провокаторів ХГН мають різноспрямований характер завдяки представленим механізмам його дії, що можуть як посилювати негативний вплив на патогенез захворювання, так і зменшувати вираженість запалення, що має позитивне значення. Можливо, більш низький рівень IL-4 в 2 гр, корелюючий з антигеном-провокатором В8, який обумовлює і стероїдорезистентність, є більш негативним фактором щодо перебігу ГН саме у його носіїв. 


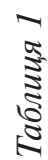

ค

ริ)

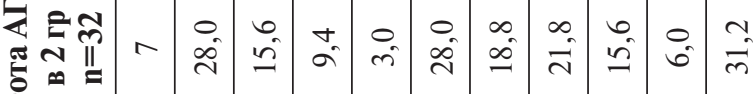
疍

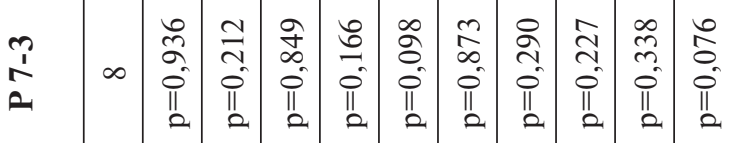

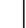

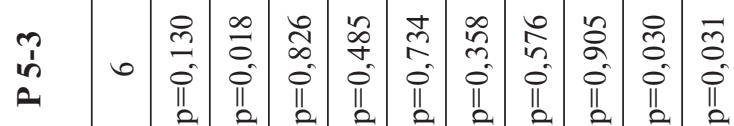

喵

to

定

西

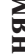

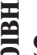

要

垔

Uำ



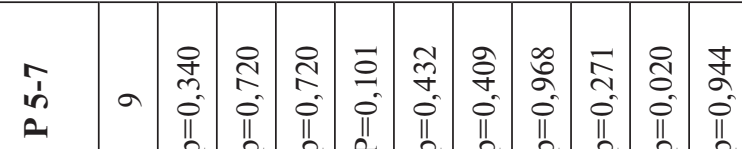

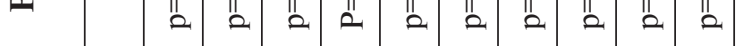

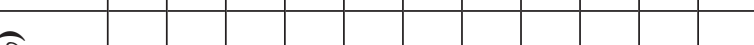

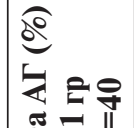

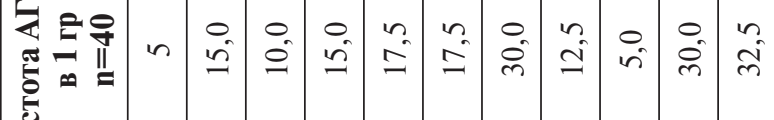
覀

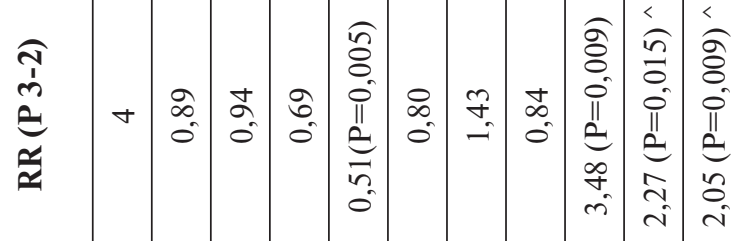

ริ

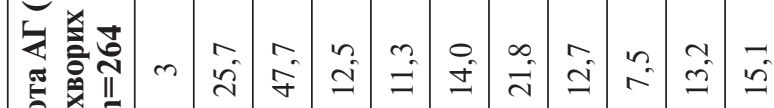
告

ริ

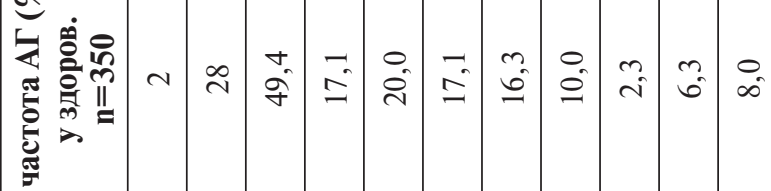$$
\text { 当 }
$$

胥

.

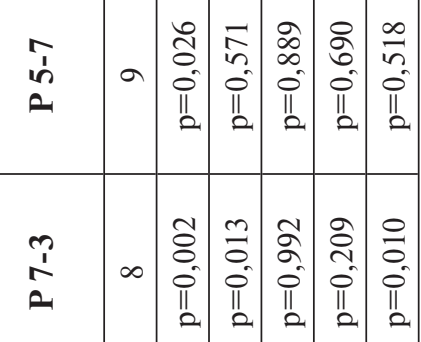

so

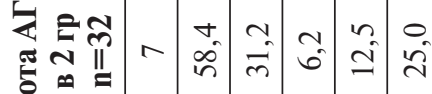

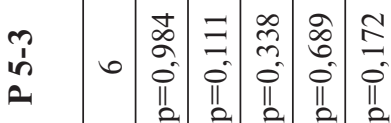

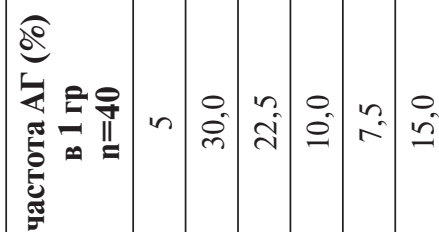

을

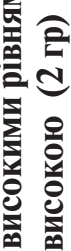

青

बิ

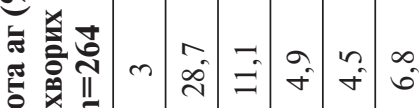

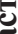

ชิ

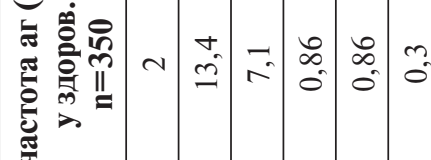

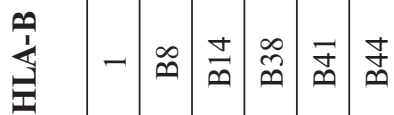

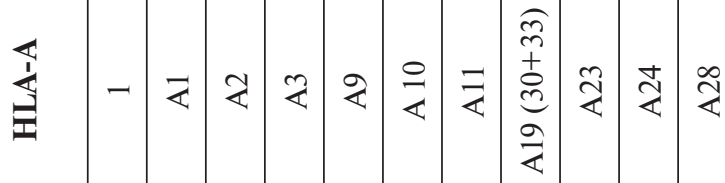


Таблиця 3

Частота HLA-DR у хворих на XГH, НС з найбільш високими рівнями IL-4 в крові - 1 гр (4) в порівнянні з частотою цих антигенів у всіх пацієнтів (3) та хворих з менш високою продукцією цитокіну IL-4 (6)

\begin{tabular}{|c|c|c|c|c|c|c|}
\hline HLA- DR & $\begin{array}{c}\text { частота аг (\%) у } \\
\text { здорових } \\
\mathrm{n}=111\end{array}$ & $\begin{array}{c}\text { частота аг (\%) у } \\
\text { хворих } \\
\mathrm{n}=30\end{array}$ & $\begin{array}{c}\text { частота аг } \\
(\%) \text { в 1 гр } \\
\mathrm{n}=13\end{array}$ & Р 4-3 & $\begin{array}{c}\text { частота аг } \\
\text { (\%) в 2 гр } \\
\mathrm{n}=16\end{array}$ & Р 4-6 \\
\hline 1 & 2 & 3 & 4 & 5 & 6 & 7 \\
\hline DR1 & 19,0 & $33,3^{* \wedge}$ & 30,0 & $>0,05$ & 37,5 & $>0,05$ \\
\hline DR2 & 44,0 & 26,7 & 38,5 & $>0,05$ & 25,0 & $>0,05$ \\
\hline DR3 & 31,5 & 20,0 & 39,0 & $>0,05$ & 25,0 & $>0,05$ \\
\hline DR4 & 5,0 & $26,7^{* \wedge}$ & 15,5 & $>0,05$ & - & \\
\hline DR5 & 43,2 & 40,0 & 53,8 & $>0,05$ & 25,0 & $>0,05$ \\
\hline DR7 & 47,0 & 30,0 & 38,5 & $>0,05$ & 37,5 & $>0,05$ \\
\hline
\end{tabular}

$*-\mathrm{RR}>2, \wedge-\sigma>0,1$

Досліджено середній рівень IL-17 у 87 обстежених нами хворих на ХГН, НС. Він перевищував рівень у здорових донорів і склав відповідно $-20,3 \pm 1,3$ пкг/мл порівняно з 9,8 $\pm 0,9$ пкг/мл $(\mathrm{p}<0,001)$. Із 79 протипованих пацієнтів до 1 гр. увійшли 32 пацієнти з рівнем IL-17, що втричі перевищував норму (вище 25 пкг/мл), інші складали 2 групу (47 хв). Порівняння груп показало досто- вірну різницю середніх рівнів IL-17 - відповідно, $34,6 \pm 2,2$ та $16,9 \pm 0,7$ пкг/мЛ $(\mathrm{p}<0,001)$.

У хворих з найбільш високою продукцією цього цитокіну - 1 гр (32 хв) достовірно частіше, ніж в цілому у пацієнтів з ХГН, НС, виявляються HLA-A24 i A28 $(\mathrm{p}<0,05)$, i різниця для A24 між 1 i 2 гр., рівень IL-17 в якій наближений до норми, достовірна (табл. 4).

Таблиия 4

Частота HLA локусу А у хворих на ХГН, НС з найбільш високими рівнями IL-17 в крові (1 гр) в порівнянні з такою у всіх пацієнтів (3) та хворих з менш високою (2 гр) продукцією цитокіну

\begin{tabular}{|c|c|c|c|c|c|c|c|c|}
\hline HLA-A & $\begin{array}{c}\text { частота } \\
\text { АГ (\%) } \\
\text { у здоров. } \\
\text { n=350 }\end{array}$ & $\begin{array}{c}\text { частота } \\
\text { АГ (\%) } \\
\text { у хворих } \\
\text { n=264 }\end{array}$ & RR (P 3-2) & $\begin{array}{c}\text { частота } \\
\text { АГ (\%) } \\
\text { в } 1 \text { гр } \\
\text { n=32 }\end{array}$ & P 5-3 & $\begin{array}{c}\text { частота } \\
\text { АГ (\%) } \\
\text { в } 2 \text { гр } \\
\text { n=47 }\end{array}$ & P 7-3 & P 5-7 \\
\hline 1 & 2 & 3 & 4 & 5 & 6 & 7 & 8 & 9 \\
\hline A1 & 28 & 25,7 & 0,89 & 9,4 & $\mathrm{p}=0,028$ & 25,5 & $\mathrm{p}=0,968$ & $\mathrm{p}=0,121$ \\
\hline $\mathrm{A} 2$ & 49,4 & 47,7 & 0,94 & 18,8 & $\mathrm{p}<0,001$ & 17 & $\mathrm{p}<0,001$ & $\mathrm{p}=0,921$ \\
\hline A3 & 17,1 & 12,5 & 0,69 & 12,4 & $\mathrm{p}=0,795$ & 10,6 & $\mathrm{p}=0,936$ & $\mathrm{p}=0,913$ \\
\hline A9 & 20,0 & 11,3 & $0,51(\mathrm{P}=0,005)$ & 12,4 & $\mathrm{p}=0,090$ & 10,6 & $\mathrm{p}=1,000$ & $\mathrm{p}=0,913$ \\
\hline A 10 & 17,1 & 14,0 & 0,80 & 25 & $\mathrm{p}=0,976$ & 25,5 & $\mathrm{p}=0,202$ & $\mathrm{p}=0,834$ \\
\hline A11 & 16,3 & 21,7 & 1,43 & 35,7 & $\mathrm{p}=0,343$ & 19,1 & $\mathrm{p}=0,842$ & $\mathrm{p}=0,340$ \\
\hline A19 $(30+33)$ & 10,0 & 12,7 & 0,84 & 18,8 & $\mathrm{p}=0,333$ & 19,1 & $\mathrm{p}=0,195$ & $\mathrm{p}=0,803$ \\
\hline A23 & 2,3 & 7,5 & $3,48(\mathrm{P}=0,009)$ & 9,4 & $\mathrm{p}=0,028$ & 12,7 & $\mathrm{p}=0,041$ & $\mathrm{p}=0,913$ \\
\hline $\mathrm{A} 24$ & 6,3 & 13,2 & $2,27(\mathrm{P}=0,015)^{\wedge}$ & 35,7 & $\mathrm{p}=0,038$ & 8,5 & $\mathrm{p}=0,460$ & $\mathrm{p}=0,025$ \\
\hline A28 & 8,0 & 15,1 & $2,05(\mathrm{P}=0,009)^{\wedge}$ & 40,6 & $\mathrm{p}=0,005$ & 27,7 & $\mathrm{p}=0,096$ & $\mathrm{p}=0,340$ \\
\hline
\end{tabular}

$\wedge-\sigma>0,1$

Якщо співставити хворих, у фенотипі яких є антиген A24 (14 хв) та його немає (65 хв), то різниця середніх рівнів IL-17 достовірна - відповідно, 26,4 $[22,5 ; 31,9]$ та $20,5[16,1 ; 27,7](\mathrm{p}=0,048)$ (рисунок); аналогічний аналіз для А28 не виявив різниці сироваткових рівнів IL-17 - 27,4 22,6 проти $22,8 \pm 1,5$ пкг/мл $(\mathrm{p}=0,109)$.
Виявлена нами асоціація високих рівнів IL-17, так само як і прозапальних TNF $\alpha$, MCP-1, IL-18, 3 наявністю в фенотипі антигенів ризику ХГН, НС A24 (відносний) і А28 (абсолютний), свідчить про важливу прозапальну дію цього лімфокіну (рис. 1). 


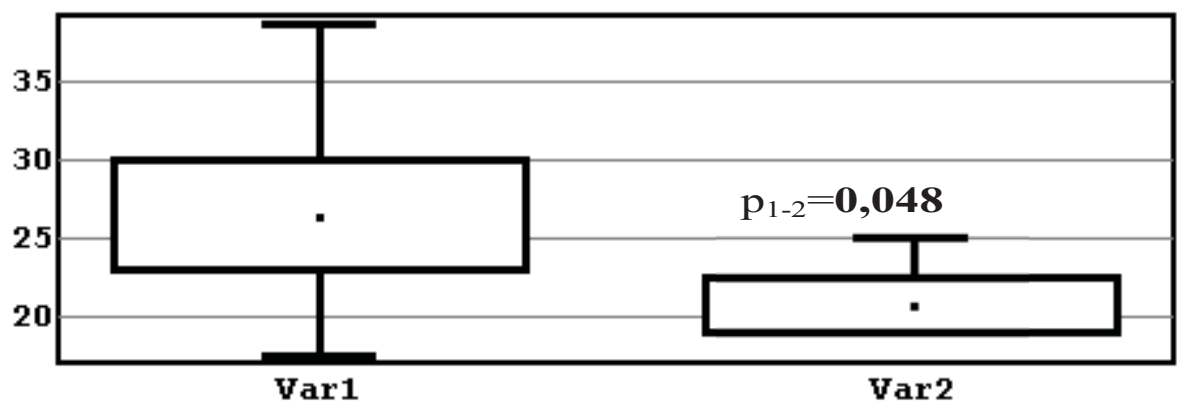

Рис. 1. Середні сироваткові рівні IL-17 в групі носіїв HLA-A24 (1) в порівнянні з іншими пацієнтами (2).

Антиген HLA-A1 зустрічався в 1 гр $з$ достовірно меншою частотою, ніж в цілому у хворих на ХГН $-\mathrm{p}=0,028$ (табл. 4).

У хворих на ХГН, НС з найбільш високими рівнями IL-17 в крові (1 гр) за локусами HLA-B та HLA-DR достовірно частіше, ніж у всіх обстежених хворих, виявляються антигени HLA-B14 та HLA-B38 (який обумовлює високий відносний ризик розвитку захворювання); за частотою В14 групи 1 і 2 достовірно різняться (табл. 5).

Таблиия 5

Частота HLA локусу В у хворих на XГН, НС з найбільш високими рівнями IL-17 в крові (1 гр) в порівнянні з такою у всіх пацієнтів (3) та хворих з менш високою (2 гр) продукцією цитокіну

\begin{tabular}{|c|c|c|c|c|c|c|c|c|}
\hline HLA-A & $\begin{array}{c}\text { частота } \\
\text { АГ (\%) у } \\
\text { здоров. } \\
\text { n=350 }\end{array}$ & $\begin{array}{c}\text { частота } \\
\text { АГ (\%) } \\
\text { у хворих } \\
\text { n=264 }\end{array}$ & P 3-2 & $\begin{array}{c}\text { частота } \\
\text { АГ (\%) } \\
\text { в } 1 \text { гр } \\
\text { n=32 }\end{array}$ & P 5-3 & $\begin{array}{c}\text { частота } \\
\text { АГ (\%) } \\
\text { в } 2 \text { гр } \\
\text { n=47 }\end{array}$ & P 7-3 & P 5-7 \\
\hline 1 & 2 & 3 & 4 & 5 & 6 & 7 & 8 & 9 \\
\hline B8 & 13,4 & 28,7 & $2,56(\mathrm{p}<0,001)^{\wedge}$ & 35,7 & $\mathrm{p}=0,772$ & 32 & $\mathrm{p}=0,772$ & $\mathrm{p}=0,858$ \\
\hline B14 & 7,1 & 11,1 & $1,59(p=0,165)$ & 50 & $\mathrm{p}=0,019$ & 17 & $\mathrm{p}=0,188$ & $\mathrm{p}=0,005$ \\
\hline B38 & 0,86 & 4,9 & $5,97(p=0,004)$ & 6,2 & $\mathrm{p}=0,006$ & 8,5 & $\mathrm{p}=0,004$ & $\mathrm{p}=0,952$ \\
\hline B41 & 0,86 & 4,5 & $5,50(p=0,007)$ & 18,8 & $\mathrm{p}=0,413$ & 10,6 & $\mathrm{p}=0,413$ & $\mathrm{p}=0,499$ \\
\hline B44 & 0,3 & 6,8 & $24,32(\mathrm{p}<0,001)$ & 18,8 & $\mathrm{p}=0,081$ & 19,1 & $\mathrm{p}=0,028$ & $\mathrm{p}=0,803$ \\
\hline
\end{tabular}

$\wedge-\sigma>0,1$

Звертає увагу, що ці обидва антигени (В14 і 38) частіше виявляються у стероїдочутливих пацієнтів. Цей факт можемо пояснювати , спираючись на публікації щодо протизапальних ефектів IL-17, коли автори вказують на одне походження Т хелперів 17 (продукуючих IL-17) із T-регуляторними клітинами (продукуючими протизапальні IL-10 та TGF- ) і можуть діяти з ними сінергічно [11].

Різниця між групами 1 і 2 достовірна також для антигену HLA-DR5 (табл. 6).

Таблиия 6

Частота HLA-DR у хворих на ХГН з найбільш високими рівнями

IL-17 в крові - 1 гр (4) в порівнянні з частотою цих антигенів у всіх пацієнтів (3) та хворих з менш високою продукцією лімфокіну (6)

\begin{tabular}{|c|c|c|c|c|c|c|}
\hline HLA- DR & $\begin{array}{c}\text { Частота аг у } \\
\text { здорових (\%) } \\
\mathrm{n}=111\end{array}$ & $\begin{array}{c}\text { частота аг у } \\
\text { хворих (\%) } \\
\mathrm{n}=30\end{array}$ & $\begin{array}{c}\text { частота аг в 1 } \\
\text { гр (\%) } \\
\mathrm{n}=12\end{array}$ & Р 4-3 & $\begin{array}{c}\text { частота аг в } \\
2 \text { гр (\%) } \\
\mathrm{n}=14\end{array}$ & Р 4-6 \\
\hline 1 & 2 & 3 & 4 & 5 & 6 & 7 \\
\hline DR1 & 19,0 & $33,3^{* \wedge}$ & 33,3 & $>0,05$ & 28,6 & $>0,05$ \\
\hline DR2 & 44,0 & 26,7 & - & $>0,05$ & 42,9 & \\
\hline DR5 & 43,2 & 40,0 & 75 & $<0,05$ & 14,3 & $<0,05$ \\
\hline DR7 & 47,0 & 30,0 & 33,3 & $>0,05$ & 42,9 & $>0,05$ \\
\hline
\end{tabular}

$*-\mathrm{RR}>2,{ }^{\wedge}-\sigma>0,1$ 
Таким чином, з найбільш високою продукцією IL-17 у хворих асоціюють антигени HLA-A24, A28, а також В14 і В38 (атрибутивний ризик), які асоційовані зі стероїдочутливістю пацієнтів, та DR5. Вважаємо, що ці результати обумовлені як про-, так і протизапальними ефектами даного лімфокіну, що ще раз підкреслює складні взаємозв'язки в комплексі імунної відповіді в цілому і ,зокрема, цитокінової ланки.

На відміну від прозапальних, не виявлено достовірних зв'язків IL-4 та IL-17 з антигенамипредикторами розвитку ХНH (HLA-10, -29, -30, -41, -51, -DR4; атрибутивний ризик - HLA-A10) [5].

Таким чином, виявлені асоціації підтверджують важливу роль антигенів А24, А28, В8, В14, B38, В44 та лімфокінів IL-4, IL-17, їх взаємозв'язку в розвитку та прогресуванні ХХH, ГН.

\section{ЛІТЕРАТУРА:}

1. Дьяченко П. А. Клетки Тh-17 и их роль в возникновении аутоимунных заболеваний (Обзор литературы) / П. А. Дьяченко, А. Г. Дьяченко // Імунологія та алергологія. - 2011. - № 2. C. 4-9.

2. Жданов A. В. Особенности корреляционных связей в системе цитокинов / А. В. Жданов, Г. Т. Сухих, М. П. Давыдова // Бюл. Экспер. биол. и медицины. - 2003. - № 9. - С. 309-311.

3. Зарецкая Ю. М. Клиническая иммуногенетика / Ю. М. Зарецкая // М. : Медицина, 1983. 103 c.

4. Колесник М. О. Особливості показників цитокінової ланки імунітету та їх прогностичне значення у хворих на хронічний гломерулонефрит / М. О. Колесник, В. Є. Дріянська, М. Б. Величко [та ін.] // Український журнал нефрології та діалізу. - 2013. - № 3 (39). - С. 28-35.

5. Колесник M. О. НLA-фенотип у хворих на хронічний гломерулонефрит з нефротичним синдромом / М. О. Колесник [та ін.] // Журнал НАМН України. - 2014. - Т. 20, № 2. - С. 206211.

6. Колесник M. О. Асоціативні зв»язки НLA з високим рівнем прозапальних цитокінів крові у хворих на хронічний гломерулонефрит / Колесник М. О., Дріянська В. Е., Величко М. Б. [та ін.] // Український журнал нефрології та діалізу. 2017. - № 1. - С. 35-41.

7. Одинеи Ю. В. Изменения уровней ИЛ-1, ФНО- $\alpha$ и ИЛ-4 в плазме крови детей с различными синдромами гломерулонефрита / Ю. В. Одинец, Л. Е. Латышев // Медицина сьогодні і завтра. 2006. - № 3-4. - С. 105-108.

8. Щербань Т. Д. Зміни активності цитокінів та міжклітинної адгезії нейтрофільних грану- лоцитів у хворих 3 прогресуючими нефропатіями в динаміці лікування / Т. Д. Щербань, I. I. Топчій // Український терапевтичний журнал. - 2003. - № 3. - С. 50-52.

9. Ярилин А. А. Симбиотические взаимоотношения клеток иммунной системы / А. А. Ярилин / Иммунология. - 2001. - № 4. - С. 16-21.

10. Cornish A. L. Suppressor of cytokine signaling-1 has IFN-gamma-independent actions in T cell homeostasis / A. L. Cornish // J. Immunol. - 2003. V. 170 , N. 2. - P. 878-886.

11. Deshpande $P$. Cutting edge : CNS CL $11 \mathrm{c}+$ cells from mice with encephalomyelitis polarise Th17 cells and support CD25+CD4+ T cell-mediated immunosuppression suggesting dual roles in the disease process / P. Deshpande // J. Immunol. 2007. - V. 178 (11). - P. 6695 - 6699.

12. Fukagawa K. IL-4 Induces eotaxin production in corneal keratocytes but not in epithelial cells / K. Fukagawa, H. Saito, K. Tsubota [et al.] // J. Allergy and Immunology. - 2000. - V. 121, N. 2. - P. 144-151.

13. Herberth $G$. IL-17E but not IL-17A is associated with allergic sensitiation: results the ELISA study / G. Herberth, C. Daegelmann, S. Roder [et al.] // Pediatr. Allergy. Immunol. - 2010. - V. 21. P. 1086-1090.

14. Langston H. P. Secretion of IL-2 and IFN-gamma, but not IL-4, by antigen-specific $\mathrm{T}$ cells requires extracellular ATP / H. P. Langston [et al.] // J. Immunol. - 2003. - V. 170, N. 6. - P. 2962-2970.

15. Park Cheol Whee. Urinary Soluble HLA Class 1 Antigen in Patients with Minimal Change Disease : A Predictor of Steroid Response / Cheol Whee Park [et al.] // Nephron. - 1998. - 79. - P. 44-49.

16. Otani Koji. Anti-inflammatory effects of IL-17A on Helicobacter pylori-induced gastritis / Koji Otani, Toshio Watanabe, Tetsuya Tanigawa [et al.] // Biochemical and Biophysical Research Communications. - 2009. - Vol. 382, Issue 2. P. 252-258.

17. Pourgholaminejad Arash. Is TGF as an antiinflammatory cytokine required for differentiation of inflammatory TH17 cells / Arash Pourgholaminejad, Nasser Aghdami, Hossein Baharvand \& Seyed Mohammad Moazzeni // Journal of Immunotoxicology. 2016. Vol. 13, N 6. - P. 775-783.

18. Yan Ke. Anti-Inflammatory Role of IL-17 in Experimental Autoimmune Uveitis / Ke Yan, Ke Liu, Guo-Qiang Huang [et al.] // The Journal of Immunology. - 2009. - 182 (5). - P. 3183-90.

Надійшла до редакції 22.05.2017 Прийнята до друку 01.06.2017 